\title{
Trade Openness and Economic Growth in Nigeria
}

\author{
Babatunde Afolabi PhD \\ Department of Banking and Finance, Afe Babalola University, Ado Ekiti \\ Bolade Oyelekan \\ Department of Economics, Afe Babalola University, Ado Ekiti
}

\begin{abstract}
The study examined the effect of trade openness on the economic growth of Nigeria, using the Gross Domestic Product (GDP) as the dependent variable. Secondary data were used spanning from the year 1981 to 2018. Ordinary Least Squares (OLS) was used to estimate the effect of openness of trade on economic growth in Nigeria. Data for the study were sourced from World Development Indicators of the World Bank and the Central Bank of Nigeria (CBN) Statistical Bulletin. Results of the analysis indicate that trade openess has positive effect on economic growth in Nigeria, with an evidence of a long-run relationship. Results also contravene the $a$ priori in the case of export and import which showed negative and positive signs respectively. For the reason above, it was recommended among others that an enabling environment should be provided by the government in the areas of infrastructural facilities to boost domestic production to enable them produce goods and services that can compete with their foreign counterparts in the international market to enhance further growth in Nigerian economy.
\end{abstract}

Keywords: Trade Openness, Economic Growth, Gross Domestic Product.

JEL Classification: F18, F21, O11, 047

DOI: $10.7176 / \mathrm{JESD} / 11-4-19$

Publication date: February $29^{\text {th }} 2020$

\section{INTRODUCTION}

Trade openness may be referred to as the degrees to which a country or economy allows or have trade with other countries or economies of the world. The trading activities include import and export, foreign direct investment (FDI), borrowing and lending, and repatriation of funds abroad. The openness rate of a country is calculated as the proportion of foreign trade volume to GDP besides the usage of the proportion of import to GDP Romer (2009) and the rate of export increase Sulaiman (2010).

Openness also means the dependence of the country on the foreign trade. Economists generally see the concept of trade openness as the integration among the nations of the world. It is similar to openness of the world economy where nations come together to the extent that they have free trade, free movement of capital and financial activities. Openness to trade can be said to be the platform of globalization while trade, finance, investment and entrepreneurs constitutes the heart.

Trade has been an area of interest to policy makers as well as economists. It allows nations of the world to sell their locally produced goods to other countries of the world. It has been regarded as an agent of growth which leads to often improvement in human status by expanding the range of people's standard of living and preferences Adewuyi (2002).

Economic growth may be defined as the increase in per capita gross domestic product (GDP) or other measures of aggregate income. It is the annual increases in a country's total output of goods and services. With globalization and trade liberalization, one of the basic interests in development and international economics is to check if trade openness promotes economic growth. The idea that trade openness affects economic growth is not new again. However, the nature of the effect is being seriously debated in the literature.

Nigeria as a developing country has been on the developmental process not only politically and socially but also economically. In 1960s, agriculture was the major source of revenue of the economy and the most important foreign exchange earner which makes it possible for the Nigerian government to execute investment projects through domestic savings, earnings from exports of agricultural products and foreign aids Ezike, et al (2012). But since the discovery of oil in commercial quantity, oil became the major source of foreign exchange earning which led to stagnation in agricultural exports. This led to loss of Nigeria's position as an important producer and exporter of palm oil produce, groundnut, cocoa and rubber. Between the year 1960 and 1980, agricultural and agro-allied exports constituted an average of sixty percent of total export in Nigeria, which is now accounted for, by petroleum oil export. This dominance of fuel exports has made Nigeria highly dependent on developments in the world oil market and prevented it from taking advantage of various opportunities in other sectors of the economy. Previous attempts to improve the non-fuel exports through export subsidies and other incentive measures have had very limited success, as many of the programs have been undermined by fraud and corruption, Peter and Olivier (2006).

The relationship between trade and growth has been the subject of so many theoretical and empirical debate and studies Sakyi, et al (2010). It is so because in a competitive environment, prices decreases and products become 
diversified through which increased welfare emerges for the people. Gains from specialization and efficiency are also advantages of economic of trade openness. It is therefore reasonable that economies desire to be open to foreign trade. The purpose of the study is to empirically investigate the effect of trade openness on economic growth of Nigeria.

\section{REVIEW OF RELATED LITERATURE}

\section{Conceptual Framework}

Trade openness according to Okpako (2005) was defined as the ratio of foreign trade to the gross domestic product of the economy. He stated that the higher the index of openness of an economy to trade, the increase the impact of trade on that domestic economy. Atoyebi et al (2012) argued that the removal of obstacles to trade is closely and positively associated with economic growth. Utkulu and Ozdemir (2004), posited that openness of trade can raise economic growth in some countries but it may also reduce it in some other countries depending on the level of development of the country involved. In a related development, foreign direct investment (FDI) has an agreed framework definition by scholars which is an investment made to acquire a lasting management interest in a business enterprise operating in a country other than that of the investor's defined according to residence (World Bank, 1996). Similarly, import may be referred to as the amount of goods and services bought by an economy or country from other economies or countries. It is expected that there will be a low economic growth if there is high import. The variable is a withdrawal in the equilibrium equation of an economy and as such, it contributes inversely to economic growth (Nwosa, Saibu and Fakunle, 2012). Similarly, Manni and Afzai (2012) defined exports as the amount of goods and services a country sold to other countries of the world. It is expected to induce economic growth as more volume of it means more trade, more production and more income for the country. They also defined GDP as the total value of all goods and services produced within the shore of a particular country in a given period of time usually in a year. Growth in GDP means growth of the economy. According to them, this is the reason that GDP is often used as proxy for economic growth.

\section{Theoretical Literature}

The theory upon which this study is based on is the Export led Growth Hypothesis. This theory postulates a relationship between the growth of exports of an economy and the economy itself such that export extensiveness becomes one of the major contributor to economic growth. The theory posits that overall growth of economies could be generated not by increasing the amounts of labor and capital, but also by increasing exports. The theoretical rationale behind this hypothesis lies on a number of certain assumptions: that the export sector will generate positive externalities on non-export sectors through more efficient management styles and improved production Feder (1983); export expansion will lead to increase in the productivity by offering potential for scale economies; exports are likely to prevent foreign exchange constraints and can provide greater access to international markets Esfahani (1991). Evidence from literature shows that the arguments have recently been extended by the literature on endogenous growth theory which emphasizes the role of exports on long-run growth via a high rate of technological innovation and dynamic learning from abroad.

\section{Empirical Review}

The effect of trade openness on economic growth in Nigeria has generated large volume of empirical studies with mixed findings using series of data. Trade is believed to be positively related with economic growth (Smith, 1776). Therefore, this section seeks to review relevant empirical studies that have investigated the effect of trade openness on economic growth. So many opinions have continued to emerge on how trade openness or globalization can affect economic activities of a country. The reasons for these controversies has been traced to the theories of Adam Smith and David Ricardo. Smith described the principle of absolute advantage in the context of trade, using labor as the only input, since it is possible for a country not to have no absolute advantage in good, no trade will occur with the other country. Absolute advantage is the ability of a country to produce more of a good product or service than countries, Ricardo on the other hand opposed to tariffs and other restrictions on trade. Ricardo came up with the comparative advantage theory. He stated that comparative advantage is a technique used to create more efficient production and describes opportunity cost between producers with perfect competition and perfect markets where countries tend to export goods in which they have a comparative advantage. In addition to the controversies among the different schools of thought on the relationship between trade openness and economic growth, much efforts have been made by scholars to authenticate or refute the arguments of these prominent schools of thought. Ogbokor (2001) analyzed the impact of oil exports on the economic growth of Nigeria. Using OLS, he observed that economic growth reacted in an expected way to changes in the variables used in the study. He also found that $1 \%$ increase in oil exports would lead to $0.5 \%$ increase in economic growth. He concluded that export-oriented strategies should be given a more favorable support. Similarly, Akerele (2001) identified sources of instability in export earnings for the Nigeria economy for the period of seventeen years (1980-1997). He observed that political and economic factors were the major causes of instability in Nigeria's export. The influence 
of political factors on export earnings is not surprising, since the period of study coincided with the imposition of various sanctions on Nigeria for failing to adopt western-style democracy. Rodriquez and Rodrik (2001) argued that trade policy does affect the volume of trade, but there is no reason to expect the effect of growth to be similar to the consequences of change in trade volumes that arise as reductions in transport cause or increases in world demand. Greenway, Morgan, and Wright (2002) carried out an empirical study on the effect of international trade on developing countries and found out that there is a significant direct relationship between trade and economic growth, that is, international trade is a major determinant of economic growth. Irwin and Tervio (2002) suggested that countries that are more open to trade tends to experience higher growth rates and per-capita income than autarky economy. Liu, Burridge and Sinclair (2002) examined the relationship between economic growth, foreign direct investment and trade in China. The study found long run relationship between the variables and a bidirectional causality between economic growth, trade and foreign direct investment. In other stimulating study, Weisbrot and Baker (2003) argued that trade may not be the only key to rapid economic growth and development. They noted that the success of some countries that experienced accelerated growth did not follow simple path to trade liberalization because the government directs the economy through the use of subsidies. Ajayi (2003) reports that the removal of barriers to trade has increased the flow of trade by 16 percent fold in the last 50 years, with the world exports of goods and services almost tripled in real terms between 1970 and year 2000. However, the share of developing countries or third world countries contribution to world trade is still very low because their exports are predominantly primary products which do not contribute much to GDP of such countries compared to trade on manufactured or finished goods. Yew-Wah (2004) in his study reported that for the past forty years (1961-2000), the Malaysian economy grew at an impressive average rate of $6.8 \%$ per annum. The rapid growth was attributed, in part, to the remarkable success in the export-oriented industrialization policy. Shafaeddin (2005) posits that trade is necessary when an industry reaches a certain level of maturity provided it is undertaken gradually and selectively.

Oviemuno (2007) studied foreign trade as an engine of growth in developing countries taking Nigeria (19802003) as a case study; the findings showed that Nigeria's export value does not act as an engine of growth in Nigeria. Nigeria's import does not act as an engine of growth in Nigeria and that Nigeria's inflation rate also does not act as an engine of growth. Chang and Ying (2008) confirmed the positive growth effects of trade and air freight for a sample of Economic Commission for Africa (ECA) countries. Kim and Lin (2009) applied the instrument-variable threshold regression approach to 61 countries and find an income threshold level above which greater trade enhances economic growth. Below the threshold level, however, trade openness has detrimental effects on growth. Chang et al. (2009) found a positive relationship between trade openness and economic growth. For a sample of 34 African countries, Vlastou (2010) found that openness to trade has a negative impact on economic growth. He also reports a causal relationship running from openness to growth.

Sunde (2017) confirmed that the Foreign Direct Investment led growth hypothesis by empirically investigating economic growth as a function of foreign direct investment and exports in South Africa. He tested the long run relationship among economic growth, foreign direct investment and exports using the autoregressive distributed lag (ARDL) model. The empirical results confirmed co-integration between economic growth, foreign direct investment and exports. The results showed that foreign direct investment and exports promote economic growth. Granger causality analysis found uni-directional causality running from foreign direct investment to economic growth and exports and a bidirectional causality between economic growth and exports. Keho (2017) studied the impact of trade openness on economic growth in Cote d'Ivoire for the period 1965 to 2014 using ARDL bounds test and the Toda and Yamamoto Granger causality tests. The results showed that trade openness has a positive effect on economic growth both in the short and long run. More so, the study found a direct relationship between trade openness and capital formation in enhancing economic growth. Tsaurai (2017) examined the relationship among financial development, economic growth and trade openness in Argentina over the period 1994 to 2014. The study found the existence of a positive but weak uni-directional causality from financial development to trade openness to economic growth and from economic growth to trade openness in the long run. This study improves on some of the existing studies; also updates these studies in terms of detailed analysis, and contributes to the existing literature on the nexus between trade openness and economic growth in Nigeria.

\section{METHODOLOGY}

Secondary data was used for this study. Time series data covering the period between 1980 and 2018 were collected from the Central Bank of Nigeria $(\mathrm{CBN})$ and the World Development Indicators (WDI). This study analyses the impact of trade openness on economic growth in Nigeria. The following variables were covered in the data collection exercise: Gross Domestic Product, Degree of Trade Openness, Foreign Exchange rate and Foreign Direct Investment. The econometric technique used is Ordinary Least Squares (OLS) in form of multiple linear regressions and among the tests that were conducted are stationarity test using Augmented Dickey Fuller (ADF) test, co-integration and causality test to determine whether one time series data is useful in forecasting another. 


\section{Model Specification}

The model seeks to examine the impact of some trade variables on economic growth in Nigeria. Therefore, Ordinary Least Square (OLS) method will be used to determine the relationship between the GDP and these variables.

$\mathrm{GDP}=\mathrm{f}(\mathrm{DTO}, \mathrm{FDI}, \mathrm{IMP}, \mathrm{EXP})$

Specifying econometrically:

$\mathrm{GDP}=\beta_{0}+\beta_{1} \mathrm{DTO}+\beta_{2} \mathrm{FDI}+\beta_{3} \mathrm{IMP}+\beta_{4} \mathrm{EXP}+\mu$

GDP - Gross Domestic Product

DTO - Degree of Trade Openness

FDI - Foreign Direct Investment

IMP - Import

EXP - Export

$\mathrm{M}-$ Error term

\section{EMPIRICAL RESULTS}

The Augmented Dickey Fuller (ADF) test showed that all the variables were stationary at first differencing.

Result of Unit Root Test for the Variables

\section{Augmented Dickey-Fuller Test}

\begin{tabular}{lccc}
\hline Variables & ADF at level & ADF at First Difference & Status \\
\hline GDP & 0.833523 & $6.893761^{*}$ & $\mathrm{I}(1)$ \\
DTO & -2.038008 & $-8.770828^{*}$ & $\mathrm{I}(1)$ \\
FDI & 0.084561 & $-7.826335^{*}$ & $\mathrm{I}(1)$ \\
EXP & 0.093585 & $3.189723^{* *}$ & $\mathrm{I}(1)$ \\
IMP & 0.066119 & $3.624447^{*}$ & $\mathrm{I}(1)$ \\
\hline
\end{tabular}

*stationarity at $1 \% ; * *$ stationarity at $5 \%$

Sources: Author's Computation 2019

The objective of this study which is to examine the impact of trade openness on economic growth in Nigeria, the above table shows the result while the linear representation of the estimated result using the OLS equation is shown below:

$$
\begin{array}{ccc}
\mathrm{GDP}=262513.6+984461 . \mathrm{DTO}+8.651712 \mathrm{FDI}-2.6678 \mathrm{EXP}+3.2355 \mathrm{IMP} & \\
\mathrm{R}^{2}=0.8832 & \overline{\mathrm{R}}^{2}=0.8522 & \mathrm{~F}=166.53
\end{array}
$$

From the regression equation, the F-Statistic is significant, good and fit. The R-square and the adjusted Rsquare are statistically significant. The coefficient of determination of the adjusted R-square which has a coefficient of 0.8522 shows that 85.2 percent of the changes in GDP can be explained by the independent variables. Also, the Durbin-Watson Statistic of 2.18 shows there is no autocorrelation among the variables. The interpretation of the regression result is that openness to trade has enhanced economic growth. As could be seen also, only export though significant, has a negative effect on GDP. The negative relationship may not be totally unexpected because of the uncompetitive nature of the country's manufacturing sector which is accompanied with inadequate facilities and unconducive macroeconomic environment. Foreign direct investment turned out with expected sign but import did not as it showed positive sign instead of negative as a leakage. This could be due to the fact that Nigeria relies more on imports, especially in terms of productive technology and heavy equipment used in the production of more goods which generate income for Nigerians. Thus, the major import is usually productive assets that increase income and improve the economic position of the country.

The Pairwise Granger Causality test result shown in the table below. It further lends credence to the direct effect of openness in causing economic growth in the country.

Pairwise Granger Causality Tests

\begin{tabular}{lcccc} 
Sample: $1981-2018$ & & & \\
\hline Null Hypothesis: & Lag & F-Statistic & Prob. & Decision \\
\hline GDP does not Granger Cause DTO & 1 & 0.02276 & 0.88613 & Accept \\
DTO does not Granger Cause GDP & & 0.00350 & 0.00321 & Reject \\
\hline
\end{tabular}

Sources: Author's Computation 2019

Johansen co-integration test was used to investigate for possible long-run relationship between trade openness and economic growth. The choice of Johansen co integration is informed by the fact that all the series are integrated of order one. The result shows that all variables are co-integrated with GDP. This is because at one percent critical value, the likelihood ratio is greater. However, when compared to the 5 percent critical value, all the variables are co-integrated. This implies the existence of a long-run relationship between the variables. 


\section{CONCLUSION AND RECOMMENDATION}

From the analysis of data and the findings in this research, it can be concluded that trade openness has positive effect on economic growth in Nigeria. The inverse relationship between export and economic growth shown in the result as against the a priori expectation is because export is injection in the equilibrium equation which however can be explained as a function of the uncompetitive nature of the Nigerian manufacturing sector due largely to huge deficit of infrastructural facilities and weaknesses of the relevant institutions. In a similar development, import which ought to show negative sign turned out to be positive. This again was explained as a function of massive importation of productive technology and heavy equipment used in the production of more goods used in the domestic economy. Therefore, the lack of competitiveness of the nation's manufacturing sector and the massive reliance on importation of productive technology and heavy equipment used in production in the local economy are the reasons that the a priori expectation were respectively violated for export and import coefficients in the estimated equation. Nevertheless, openness to trade positively affect economic growth in Nigeria.

\section{Recommendations}

Based on the findings and the conclusion made from the findings, we made the following recommendations:

1. There is need for urgent measure in terms of policies targeted at boosting domestic production by revitalizing the ailing domestic industries to enable them produce goods that can compete with foreign goods thereby promoting the export of the country.

2. International best practices in export processing, export duties collection at the ports, financing support for exporters should also be adopted.

3. Import is expected to be a leakage, it turned out to be positive and significant, and it should be allowed. However, the country should try to avoid over-dependence on importation as this would result in exploitation, dumping and shifting of the domestic industries.

4. The co-integrated behavior of our dependent variables suggests that in the long-run, movement in trade openness, foreign direct investment, export and import could be used to raise growth in Nigerian economy. For this reason, efforts must be made to ensure that there is efficiency the external sector.

\section{REFERENCES}

Adewuyi, A. O. (2002). "Balance of Payments Constraints and Growth ate Differences under Alternative Police Regimes". Nigerian Institute of Social and Economic Research (NISER) Monograph Series No. 10 Ibadan in Nigeria.

Ajayi, S. (2003). Globalization and Africa. Journal of Africa Economics, Vol. 12, PP. 120- 150.

Akerele, A. (2001). "Nigeria's Export Trade Instability and Forecast". Journal of Development Alternatives and Area Studies, Vol. 20 (3-4). PP.61-80.

Atoyebi, K.O., Akinde, J.O., Adekunle, F.O. and Edun, F. (2012). Foreign trade and economic growth in Nigeria: an empirical analysis. American Academic and Scholarly Research Journal, 4(5): 211-223.

Chang, C. P., and Ying, Y.-H. (2008). the Generative Power of Air Freight in the Trade Openness Economic Growth Nexus in African Countries. South African Journal of Economics, 76, 493-512.

Chang, R., Kaltani, L., and Loayza, N. V. (2009). Openness can be good for Growth: The Role of Policy Complementarities. Journal of Development Economics, 90, PP.33-49.

Esfahani, H.S. (1991). Exports, imports and economic growth in semi-industrial countries. Journal of Development Economics, 35:93-116.

Ezike, J. E., Ikpesu, F., and Amah, P. (2012). "Macroeconomic Impact of Trade on the Nigerian Growth: An empirical Evaluation". Research Journal of Business Management and Accounting, Vol. 1 (4), PP.079-083.

Feder, G. (1983). Exports and economic growth. Journal of Development Economics, 12:59-73

Irwin, D., and Tervio, M. (2002). Does Trade Raise Income? Evidence from the Twentieth Century. Journal of International Economics, Vol. 58: PP.1-18

Keho, Y. (2017). "The Impact of Trade Openness on Economic Growth: The Case of Cote d'Ivoire". Cogent Economics and Finance, 5, PP.1-14.

Kim, D.-H., and Lin, S. (2009). Trade and growth at Different Stages of Economic Development. Journal of Development Studies, 45, PP.1211-1224.

Liu, X., Burridge, P., and Sinclair, J. (2002). "Relationships between Economic Growth, Foreign Direct Investment and Trade. Evidence from China". Applied Economics 34(11), PP.1433-1440.

Manni, U.H. and Afzai, M.N.I. (2012). Effect of trade liberalization on economic growth of developing countries: a case of Bangladesh economy. Journal of Business, Economics and Finance, 1(2): 3744.

Nwosa, P.I., Saibu, M.O., Fakunle, O.O. (2012). The effect of trade liberalization on trade tax revenue in Nigeria. African Economic and Business Review, 10(2): 28-43

Ogborkor, C. A. (2001). "Oil and Economic Growth: An Econometric Analysis" Journal Development 
Alternatives and Area Studies, Vol. 20 Nos. 2 and 3: PP.124-130.

Okpako, G.U. (2005). Public finance, Ikeja: Tivolick.

Oviemuno, A. (2007). "International Trade as an Engine of Growth on Developing Countries: A Case Study of Nigeria". Journal of Economics Perspective, 12(4), PP.45- 62.

Peter, W. and Olivier, C. (2006). "Trade, Diversification and Growth in Nigeria". The World Bank, Washington DC.

Rodriquez, F. and Rodrik, F. (2001). 'Trade Policy and Economic Growth: A Skeptic's Guide to the Cross National Evidence". In National Bureau of Economic Research Macroeconomics Annual 2000, Volume 15, PP 261338. MIT Press.

Romer P. M. (2009). “Increasing returns and long- run growth.” Journal of Political economy, 94, 5, October, pp. $1002-1037$

Sakyi, D., Villaverde, J., Maza, A., and Chittedi, K. (2010). “Trade Openness, Growth and Development: Evidence from Heterogeneous Panel Cointegration Analysis for Middle Income Countries". Cuadernos de Economía 31(57), PP.21-40.

Shafaeddin, M. S. (2005). "Trade Liberalization and Economic Reform in Developing countries". The IMF, World Bank and Policy Reform 155, PP.2-20.

Smith, A. (1776). The Wealth of Nations. New York: The Modern Library

Sunde, T. (2017). "Foreign Direct Investment, Exports and Economic Growth: A L and Causality Analysis for South Africa" Research in International Business and Finance 41, PP.434 444.

Sulaiman, D.M. (2010). The effectiveness of financial development and openness on economic growth: case study of Pakistan. European Journal of Social Science, 13(3): 120-129.

Tsaurai, K. (2017). "Investigating the Relationship between Financial Development, Trade Openness and Economic Growth in Argentina: A Multivariate Causality Framework". Acta Universitatis Danubius Economica. 13(3), PP.39-55

Utkulu, U. and Ozdemir, D. (2004). Does trade liberalization cause long-run economic growth in Turkey? Economic and Business Change and Restructuring, 37 (3): 245-266.

Vlastou, I. (2010). Forcing Africa to Open Up to Trade: Is it Worth It? The Journal of Developing Areas, 44, PP. 25-39

Weisbrot, M., and Baker, D. (2003). "The Relative Impact of Trade Liberalization on Developing Countries". Investigacion Economica, PP.15-55

World Bank. (1996). The East Asian miracle: Economic growth and public policy. New York, NY: Oxford University Press

Yew Wah, L. (2004). The ole of Domestic Demand in Economic Growth of Malaysia": A Co-Integration Analysis". International Economic Journal, Vol.18 (3), PP. 337-352.

\section{APPENDIX}

\section{Regression Result Outputs}

Dependent Variable D(GDP)

Method: Ordinary Least Squares

Date: $15 / 12 / 19 \quad$ Time 21:43

Sample: $1981-2018$

\begin{tabular}{lllll}
\hline \multicolumn{4}{l}{ Included Observations: 38} & \multicolumn{3}{l}{} \\
\hline Variable & Coefficient & Standard Error & t-Statistic & Prob. \\
\hline C & 273438.7 & 249866.7 & 1.1454 & 0.2634 \\
D(OPN) & 997451.2 & 465677.1 & 2.112 & 0.0123 \\
D(FDI) & 8.766712 & 2.766514 & 3.3873 & 0.0012 \\
D(EXP) & -2.776823 & 0.632430 & -5.3426 & 0.000 \\
D(IMP) & 3.346817 & 0.463865 & 9.3748 & 0.001 \\
\hline R-Squared & & 0.88321 & Mean dependent var. & 5664255 \\
Adjusted R-Squared & 0.852221 & S.D. dependent var. & 8782108 \\
S.E. of regression & & 725841.0 & Akaike infor criterion & 28.71146 \\
Sum Squared resid & & $1.90 \mathrm{E}+12$ & Schwarz criterion & 29.11734 \\
Log. likelihood & -633.1478 & Haman-Quinn criterion & 28.89730 \\
F-Statistic & 166.532 & Durbin-Watson Stat. & 2.18 \\
Prob (F-Statistic) & 0.00000 & & & \\
\hline
\end{tabular}


Ohansen Co-Integration Test Result

Test Assumption: No deterministic trend in the data Series: D(GDP) D(DTO) D(FDI) D(EXP) D(IMP)

\begin{tabular}{lcccc}
\hline Lags interval: 1 to 1 & \multicolumn{3}{c}{} \\
\hline & Likelihood & 5 Percent & 1 Percent & Hypothesized \\
\hline Eigenvalue & Ratio & Critical Value & Critical Value & No. of CE(s) \\
0.871819 & 125.56130 & 82.47 & 91.46 & None** \\
0.748217 & 96.79941 & 57.48 & 65.53 & At most $1^{* *}$ \\
0.688221 & 58.4206 & 38.87 & 46.57 & At most $2^{* *}$ \\
0.420847 & 27.88260 & 24.21 & 28.76 & At most $3^{* *}$ \\
0.138606 & 4.275615 & 3.83 & 6.52 & At most $4^{* *}$ \\
\hline
\end{tabular}

* Rejection of the hypothesis at 5\% significance level

** Rejection of the hypothesis at $1 \%$ significance level

L.R. test indicates 5 co integrating equation at $5 \%$ significance level 